Note

\section{Involvement of a Polyethylene glycol (PEG)-oxidizing Enzyme in the Bacterial Metabolism of PEG}

\author{
Fusako KawaI, Takuhei Kimura, \\ Yoshiki TANI ${ }^{\dagger}$ and Hideaki YAMADA* \\ Department of Biology, Kobe University \\ of Commerce, Kobe 655, Japan \\ * Department of Agricultural Chemistry, \\ Kyoto University, Kyoto 606, Japan
}

Received October 21, 1983

We have isolated many polyethylene glycol (PEG)utilizing bacteria and confirmed that PEG is oxidatively metabolized by a synergistic mixed culture of two bacteria which are individually unable to utilize PEG as a sole carbon and energy source. ${ }^{1 \sim 3)}$ The PEG-oxidizing enzyme was purified from the mixed culture and characterized as 2,6-dichlorophenolindophenol (DCIP)-dependent dehydrogenase. $^{3,4)}$ Other works also showed PEG-oxidizing activities in PEG-utilizing bacteria. ${ }^{5 ~ 8)}$ On the other hand, Haines and Alexander suggested that PEG 20,000 was hydrolyzed by an extracellular enzyme of a strain, Pseudomonas aeruginosa, into diethylene glycol and ethylene glycol which were incorporated and metabolized by washed cells. ${ }^{9)}$ In our experiments, ${ }^{3)}$ however, PEG 6,000 was neither hydrolyzed by an extracellular enzyme of the mixed culture nor by an intracellular one. The culture could not grow on ethylene glycol or diethylene glycol which were presumed intermediates in PEG metabolism according to the report of Haines and Alexander. Instead PEG-oxidizing activity linked with DCIP was found in sonic extracts of the mixed culture.

In the present paper we report that PEG-utilizing bacteria have PEG-oxidizing systems in their cell-free extracts and tetraethylene glycol (TEG) is oxidatively metabolized by resting cells of these bacteria.

Average molecular weights and sources of PEGs used were the same as those listed in the previous report. ${ }^{1)}$ All the PEG solutions used for measuring PEG-oxidizing activity were freshly prepared before use. PEG 400-utilizing (Nos. 42 and 43), PEG 1,000-utilizing (C-1 and Nos. $101 \sim 103$ ), PEG 4,000-utilizing (Nos. $201 \sim 204, \mathrm{D}-1$ and D-2) and PEG 20,000-utilizing (E-1) strains were isolated by the enrichment culture technique from soil and waste water and also from activated sludge samples as described previously. ${ }^{1}{ }^{1}$ All strains were maintained on PEG slants. The two strains composing E-1 were usually maintained on a PEG 6,000 slant as a mixed culture. ${ }^{2)}$ All strains were grown on a basal medium ( $\mathrm{pH}$ 7.2) containing $5 \mathrm{~g}$ of $\mathrm{PEG}$, $3 \mathrm{~g}$ of $\left(\mathrm{NH}_{4}\right)_{2} \mathrm{SO}_{4}$ or $\left(\mathrm{NH}_{4}\right)_{2} \mathrm{HPO}_{4}, 2 \mathrm{~g}$ of $\mathrm{K}_{2} \mathrm{HPO}_{4}, 1 \mathrm{~g}$ of $\mathrm{NaH}_{2} \mathrm{PO}_{4}, 0.5 \mathrm{~g}$ of $\mathrm{MgSO}_{4} \cdot 7 \mathrm{H}_{2} \mathrm{O}$ and $0.5 \mathrm{~g}$ of yeast extract in one liter of tap water. The bacteria were cultured in a 2-liter shaking flask containing $500 \mathrm{ml}$ of liquid medium with shaking at $28^{\circ} \mathrm{C}$ for 3 days (all strains except E-1) or 7 days (E-1). After cultivation, the cells were harvested by centrifugation at $8,000 \times g$ at $4^{\circ} \mathrm{C}$ for $20 \mathrm{~min}$ and washed twice with physiological saline. The washed cells were suspended in an appropriate amount of $0.05 \mathrm{M}$ potassium phosphate buffer ( $\mathrm{pH} 8.0)$, and disrupted with a $19 \mathrm{kHz}$ ultransonic oscillator (Kaijo-Denki Co., Ltd., Japan) on ice. Cell debris was removed by centrifugation at $12,000 \times g$ at $4^{\circ} \mathrm{C}$ for $20 \mathrm{~min}$. The resultant supernatant solution was used as a cell-free extract.

PEG-oxidizing activity was measured by determining a 2,4-dinitrophenylhydrazine-positive compound according to the method of Narrod and Jakoby. ${ }^{10)}$ The validity of this method was confirmed by our previous study: The formation of TEG-aldehyde and valeraldehyde from substrates, TEG and $n$-pentanol, by PEG dehydrogenase was confirmed. ${ }^{11)}$ The standard reaction mixture $(2.5 \mathrm{ml})$ contained $250 \mu \mathrm{mol}$ of potassium phosphate buffer ( $\mathrm{pH} \mathrm{8.0)}$, $100 \mathrm{mg}$ of PEG and an appropriate amount of the cell-free extract. The reaction was started by the addition of the cell-free extract and carried out at $30^{\circ} \mathrm{C}$. As a reaction blank, $0.1 \mathrm{ml}$ of $4 \mathrm{~N} \mathrm{HCl}$ was added to a reaction mixture before starting the reaction. After $20 \mathrm{~min}$ incubation, the reaction was stopped by the addition of $0.1 \mathrm{ml}$ of $4 \mathrm{~N} \mathrm{HCl}$. The reaction mixture $(1.0 \mathrm{ml})$ was boiled for $10 \mathrm{~min}$ with an equal volume of $0.1 \%$ 2,4-dinitrophenylhydrazine solution in $2 \mathrm{~N} \mathrm{HCl}$. After cooling, $5 \mathrm{ml}$ of $1 \mathrm{~N}$ alcoholic $\mathrm{KOH}(4 \mathrm{~N} \mathrm{KOH}: 99.5 \%$ ethanol=1:3), prepared immediately before use, was added, and the mixture was stirred vigorously. Then the absorbance at $580 \mathrm{~nm}$ was measured with a Hitachi double-beam spectrometer 20010. The amount of the reaction product (PEG-aldehyde) ${ }^{11}$ was calculated by reference to a standard curve prepared with glycol aldehyde. The protein content of the enzyme preparation was determined by the method of Lowry et $a l{ }^{12)}$ One unit of the enzyme was defined as the enzyme quantity which formed $1 \mu \mathrm{mol}$ of aldehyde per min. The specific activity of the enzyme was expressed in terms of the units of enzyme contained per milligram of protein.

As previously reported, ${ }^{3)}$ PEG-oxidizing activity was found in cell-free extracts of a mixed culture (E-1). To determine the mechanism by which PEG is metabolized by other PEG-utilizing bacteria, PEG-oxidizing activities of sonic extracts of PEG-utilizing bacteria grown on PEG media were investigated. The enzyme activity was found in all the PEG-utilizing bacteria (Table I). All the PEG 4,000utilizing strains and one PEG 1,000-utilizing strain, No. 103, had strong DCIP-dependent activities similar to that of the mixed culture. ${ }^{3)}$ In contrast, two strains of PEG 400-

\footnotetext{
${ }^{\dagger}$ Present Address. Research Center for Cell and Tissue Culture, Kyoto University, Kyoto 606, Japan.
} 
Table I. PEG-Oxidizing Activity in Cell-free Extracts OF PEG-UTILIZING BACTERIA

\begin{tabular}{|c|c|c|c|c|c|c|}
\hline \multirow{3}{*}{ Strain $^{a}$} & \multirow{3}{*}{$\begin{array}{l}\text { Carbon source and } \\
\text { enzyme substrate }\end{array}$} & \multirow{3}{*}{$\begin{array}{l}\text { Total protein } \\
\text { (mg) }\end{array}$} & \multicolumn{4}{|c|}{$\begin{array}{c}\text { Specific activity } \\
\text { (units/mg protein, } \times 10^{3} \text { ) }\end{array}$} \\
\hline & & & \multicolumn{4}{|c|}{ Electron acceptor ( $0.1 \mathrm{~mm})$} \\
\hline & & & None & DCIP & NAD & NADP \\
\hline 42 & PEG 400 & 100 & 2.4 & 0.3 & 1.4 & 1.9 \\
\hline 43 & PEG 400 & 164 & 1.3 & 0.6 & 1.3 & 1.4 \\
\hline $\mathrm{C}-1$ & PEG 1,000 & 56 & 0.3 & 1.7 & 0.6 & 1.1 \\
\hline 101 & PEG 1,000 & 68 & 1.8 & 2.5 & 1.2 & 2.1 \\
\hline 102 & PEG 1,000 & 59 & 1.1 & 0.6 & 1.0 & 0.7 \\
\hline 103 & PEG 1,000 & 188 & 5.1 & 30.4 & 2.7 & 1.8 \\
\hline 201 & PEG 4,000 & 219 & 2.4 & 11.2 & 0.8 & 0.4 \\
\hline 202 & PEG 4,000 & 203 & 2.9 & 12.8 & 1.1 & 0.6 \\
\hline 203 & PEG 4,000 & 194 & 2.9 & 14.1 & 1.7 & 1.6 \\
\hline 204 & PEG 4,000 & 251 & 2.2 & 8.3 & 0.4 & 0.2 \\
\hline D-1 & PEG 4,000 & 231 & 2.3 & 9.1 & 0.7 & 0.4 \\
\hline D-2 & PEG 4,000 & 237 & 2.0 & 10.3 & 1.4 & 1.5 \\
\hline E-1 & PEG 6,000 & 238 & 2.2 & 18.9 & 2.1 & 0.9 \\
\hline
\end{tabular}

a Each culture was carried out for 3 days except for E-1. E-1 was cultivated for 7 days.

$b$ Values are expressed as total protein of cell-free extracts prepared from 500-ml cultures.

c Enzyme activity was measured by determining a 2,4-dinitrophenylhydrazine-positive compound as described in the text.

utilizing bacteria and PEG 1,000-utilizing strains No. 101 and 102 showed DCIP-independent activities. The enzyme activity of strain C-1 was elicited by DCIP and NADP.

While all of the bacteria possessed enzyme activities of differing substrate specificities toward PEGs, they had only slight or no activity toward ethylene glycol (Table II). These extracts extremely oxidized PEGs close to the molecular weight range of those utilized as growth substrates by the respective strains. In addition, the cell-free extract of strain No. 103 appreciably oxidized PEG $2,000 \sim 6,000$ which were not utilized as sole carbon and energy sources by the bacterium.

From these results, there seem to be two types of PEGoxidizing enzymes; DCIP-dependent PEG-oxidizing enzymes and DCIP-independent PEG-oxidizing enzymes. PEG 400-utilizing bacteria and some of the PEG 1,000utilizing bacteria formed DCIP-independent enzymes. Other PEG 1,000-utilizing bacteria, all the PEG 4,000utilizing bacteria and E-1 possessed DCIP-dependent enzymes. The fact that PEG-oxidizing enzymes are present in all the PEG-utilizing bacteria reveals that PEG is oxidatively metabolized by these strains.

Washed cells of PEG-oxidizing bacteria obtained from $100-\mathrm{ml}$ cultures were incubated with $0.2 \mathrm{~g}$ of TEG in $20 \mathrm{ml}$ of $0.01 \mathrm{M}$ potassium phosphate buffer $\left(\mathrm{pH} \mathrm{7.2)}\right.$ at $28^{\circ} \mathrm{C}$ for one day with shaking. The strains used were the same as those used for testing PEG-oxidizing activities of sonic extracts were. The reaction was stopped by centrifuging the mixture at $10,000 \times g$ for $20 \mathrm{~min}$; intact cells were then
Table II. OXIDizing Activity toward Several PEGS in CELl-free Extracts of Typical PEG-UTILIZING BACTERIA

\begin{tabular}{lrrrrr}
\hline & \multicolumn{5}{c}{$\begin{array}{c}\text { Specific activity } \\
\left.\text { (units/mg protein, } \times 10^{3}\right)^{b}\end{array}$} \\
\cline { 2 - 6 } Substrate $^{a}$ & \multicolumn{5}{c}{ Strain } \\
\cline { 2 - 6 } & 42 & 101 & 103 & 203 & E-1 \\
\hline Ethylene glycol & 0.2 & 0.0 & 0.2 & 0.2 & 0.0 \\
Tetraethylene glycol & 4.4 & 8.2 & 7.1 & 4.7 & 9.2 \\
PEG 400 & 3.3 & 6.5 & 7.3 & 7.4 & 12.2 \\
PEG 1,000 & 0.9 & 2.0 & 4.3 & 4.0 & 7.6 \\
PEG 2,000 & 0.4 & 0.4 & 2.9 & 2.1 & 4.4 \\
PEG 4,000 & 0.5 & 0.3 & 2.6 & 1.7 & 3.9 \\
PEG 6,000 & 0.5 & 0.4 & 0.7 & 0.5 & 1.3 \\
\hline
\end{tabular}

a Final concentration of $5 \mathrm{~mm}$.

$b$ Enzyme activity was measured by determining a 2,4dinitrophenylhydrazine-positive compound as described in the text.

removed. TEG and its metabolites were separated on a $0.25 \mathrm{~mm}$-thick silica gel $60 \mathrm{~F}_{254}$ plates (E. Merck). The chromatograms were developed with 1-propanol-ethanolwater $(50: 30: 20, \mathrm{v} / \mathrm{v} / \mathrm{v})$. TEG and its metabolites were detected with a $\mathrm{K}_{2} \mathrm{Cr}_{2} \mathrm{O}_{7}-\mathrm{H}_{2} \mathrm{SO}_{4}$ reagent. ${ }^{13)}$ Authentic TEG-monocarboxylic acid and TEG-dicarboxylic acid 
were prepared and identified as described previously. ${ }^{3)}$ TEG and triethylene glycol were commercially obtained and showed single peaks, respectively, on gas chromatography which was carried out under the same conditions as described previously. ${ }^{3)}$ All the strains metabolized TEG and formed metabolites with the same $R f$ values as authentic TEG-monocarboxylic acid, TEG-dicarboxylic acid and triethylene glycol. TEG-monocarboxylic acid was the common main product formed by all the strains, but fluctuations were observed in the formation of TEGdicarboxylic acid and triethylene glycol by these strains.

From these results, we can conclude that oxidative degradation is common to the metabolism of PEG by aerobic bacteria. Our previous report showed that PEG dehydrogenase of a PEG 20,000-utilizing synergistic mixed culture was membrane-bound and was solubilized with laurylbetaine. ${ }^{4)}$ It will be interesting to see whether the other PEG-oxidizing enzymes are membrane-bound or not.

\section{REFERENCES}

1) K. Ogata, F. Kawai, M. Fukaya and Y. Tani, J. Ferment. Technol., 53, 757 (1975).
2) F. Kawai, M. Fukaya, Y. Tani and K. Ogata, $J$. Ferment. Technol., 55, 429 (1977).

3) F. Kawai, T. Kimura, M. Fukaya, Y. Tani, K. Ogata, T. Ueno and H. Fukami, Appl. Environ. Microbiol., 35, 679 (1978).

4) F. Kawai, T. Kimura, Y. Tani, H. Yamada and M. Kurachi, Appl. Environ. Microbiol., 40, 701 (1980).

5) W. J. Payne, Biotech. Bioeng., 5, 355 (1963).

6) W. J. Payne and R. L. Todd, J. Bacteriol., 91, 1533 (1966).

7) S. Ohmata, N. Kojima and T. Sakai, J. Ferment. Assoc. Jpn., 32, 196 (1974).

8) T. Harada and Y. Sawada, J. Ferment. Technol., 55, 553 (1977).

9) J. R. Haines and M. Alexander, Appl. Microbiol., 29, 621 (1975).

10) S. A. Narrod and W. B. Jakoby, J. Biol. Chem., 239, 2189 (1964).

11) F. Kawai, T. Kimura, Y. Tani, H. Yamada, T. Ueno and H. Fukami, Agric. Biol. Chem., 47, 1669 (1983).

12) O. H. Lowry, N. J. Rosebrough, A. L. Farr and R. J. Randall, J. Biol. Chem., 193, 265 (1951).

13) G. Zweig and J. Sherma (ed.), "Handbook of Chromatography," Vol. 2, CRC Press Inc., Cleveland, Ohio, 1972, p. 145. 